\title{
MUSEUM SCIENCE EDUCATION IN THE PANDEMIC ERA
}

\author{
Eleni Kolokouri ${ }^{1}$, Athina C. Kornelaki ${ }^{2}$, Katerina Plakitsi ${ }^{3}$ \\ University of Ioannina (Greece)
}

\begin{abstract}
This paper presents the development of a distance learning course for pre-service teachers which focuses on science education in museums with the use of technology. The purpose was mainly to adapt to the new situation of the pandemic, and offer pre-service teachers an online version of the course following an expansive learning cycle. Towards this direction, the course 'The Role of the Museum in Science and Technology Education' was developed in an online version, so as to connect science education and technology with the museums, and is addressed to pre-service teachers during the last year of their studies. Cultural Historical Activity Theory (CHAT) was used as a theoretical framework for the design and the analysis of the course. The methodology followed in an expansive learning cycle with the participation of 88 pre-service teachers. The results presented in this paper concern pre-service teachers' views about distance museum education, conflicts during the distance learning course, and the connections of scientific topics with the 17 Sustainable Development Goals that pre-service teachers made. The development of this course shows an example of alternative methods of learning that can be implemented in crisis situations.
\end{abstract}

KEY WORDS: museum, science education, CHAT.

JEL CODES: I0, I00, I000.

DOI: http://dx.doi.org/10.15181/rfds.v34i2.2247

\section{Introduction}

A date that will always be remembered by the education community in Greece is 10 March 2020, when all the educational institutions proceeded to a lockdown due to the pandemic situation of Coronavirus. This was the first of a series of measures taken in a great crisis all over the world, which led to a fundamentally new era completely different from what already existed. The pandemic that began in one country and spread out in an accelerating pace around the world is a global crisis seeking a global response. The change of global leadership, questioning of globalisation, free trade, economic decline, and possible regime change in several countries are new elements that might lead the world to a turning point in modern history. Furthermore, social distancing, new rules of hygiene, and research about the availability of drugs and vaccinations to confront the pandemic have caused crisis situations from an environmental, economic and social point of view. As a result, the equal balance of the three pillars of sustainable development, that is, the environment, society and the economy, have been ruptured, and a new kind of crisis came to the fore.

Crisis in the ancient Greek language was defined among other things as decision, choice, election and judgement, which points out the dimension of progress and development. In psychology, crisis is a key concept, which addresses change and development, at different levels. Crisis can typically be connected with a

1 Eleni Kolokouri - laboratory teaching staff, Department of Early Childhood Education, School of Education, University of Ioannina, Ioannina, Greece

E-mail: ekolokouri@uoi.gr

2 Athina-Christina Kornelaki - post-doctoral researcher, Department of Early Childhood Education, School of Education, University of Ioannina, Ioannina, Greece

E-mail: akornelaki@uoi.gr

3 Katerina Plakitsi - full professor, head of the Department of Early Childhood Education, School of Education, University of Ioannina, Ioannina, Greece

E-mail: kplakits@uoi.gr 
form of resistance or revolution, and can bring about a transformation in society due to political, economic or environmental reasons, which can lead to the creation of historical events. The conflicts that arise from crisis situations can seriously affect society as well as the individual, and cause changes displayed as tensions or incidents seeking resolution and development (Dafermos, 2014; Zittoun, 2019). Within this framework, education at all levels was seriously affected by the instant lockdown. All academic institutions closed, and more than $90 \%$ of the world's learners could not go to schools and institutions in 190 countries and regions, according to the United Nations Educational, Scientific and Cultural Organization (UNESCO, 2020). Accordingly, everything changed in the university community. The buildings were locked down, events were cancelled, and remote connections were made only in case of an emergency. In a very short time, all academic activities, such as courses, seminars, workshops, research work, examination arrangements and graduation, were arranged with the aid of distance learning. This rapid and forced adoption of distance teaching and learning in the universities first, and after a month at all levels of education, brought about a new era in education, and raised complex or even controversial issues, such as inequality in education, learning environments at home, access to on-line learning platforms, lack of appropriate teacher training, and new methodologies and pedagogies of distance learning.

Nevertheless, the role of education in this crisis situation was to support learning communities, both students and families, to provide distance learning opportunities to improve access to digital education in vulnerable environments, and, finally, to make learning an interesting era, and work on the development of new skills. In this sense, distance learning courses were organised by the Department of Early Childhood Education in Ioannina to make ends meet and cover all subjects during the lockdown.

This paper presents the development of a distance learning course for pre-service teachers which focuses on science education in museums with the use of technology. The purpose was mainly to adapt to the new situation of the pandemic, and offer pre-service teachers an online version of the course following an expansive learning cycle. The objective of the present paper is to identify the extent to which the course's learning outcomes were achieved by the university students, even though the course was offered in a distance learning mode. In order to explore the above, quantitative and qualitative data were collected and analysed.

First and foremost, students' views about museum education, and more specifically, distance learning in museum education, were taken into consideration, using an online questionnaire with closed-ended questions at the beginning of the course. The statistical analysis of the answers collected was made with SPSS software. The next step was to explore the competences students developed during the implementation of the course, the difficulties they encountered during distance learning, and whether the course's workload (assignments, mini projects, final assignment, etc) burdened or supported students' learning. All these inputs were gathered using a questionnaire at the end of the course which was analysed quantitively. The last step was to extract some more inputs from students' assignments. A key element in order for students to meet the final assignment's requirements was to be able to identify connections between the science education curriculum in early grades and the 17 Sustainable Development Goals. The latter was considered a significant indicator for students' accomplishment, and was studied qualitatively using the qualitative data analysis software NVivo.

\section{Pre-service teachers' education for the early ages: science education in museums}

Science museums and science centres are strongly connected with social change and transformative interventions in science education as a tool for scientifically literate societies and responsible citizenship. The second Science Centre World Summit (SCWS, 2017) led to the emergence of the Tokyo Protocol (November 2017), which recognises the 17 Sustainable Development Goals (SDGs) endorsed by the United Nations (2015) as principal priority in global prosperity. In this sense, Science, Technology, Engineering and Mathematics (STEM) are seen as significant factors in achieving SDGs and platforms for public engagement in global sustainability, as they compound fields universally relevant across borders and cultures (Kornelaki, Plakitsi, 2018). 
Museums are cultural institutions, and as such they can play a central role in achieving the 17 Sustainable Development Goals in an ever-changing society. Free access to all people constitutes a universal human right promoting engagement in diverse audiences and keeping the focus on gender differences. According to the Museum Association (2013), 'The best museums use their position of trust to encourage people to reflect on society's contemporary challenges. They promote social justice and human rights, challenge prejudice and champion fairness and equality.'

In museums, people can engage with scientific knowledge, they can build links between science and everyday life and discover the extent to which everyday life is affected by science, they become acquainted with their culture, and they adopt a positive stance towards science and museum (Plakitsi, 2008; Georgopoulou, Koliopoulos, 2017). The Tokyo Protocol binds science centres and museums to strive to achieve 'a positive global impact and make people of the opportunities that science and technology hold for the sustainable advancement of humankind' (SCWS, 2017).

Towards this direction, the course 'The Role of the Museum in Science and Technology Education' has been developed to connect science education and technology with the museums, and is addressed to pre-service teachers during the last year of their studies. The learning outcomes of the course focus mainly on the familiarisation and critical reflection on museums' educational programmes in teaching science subjects, the identification of the teacher's role in the design, construction and implementation of educational programmes, the design and construction of an educational programme for teaching a science subject in a museum, the design, analysis and evaluation of educational programmes inspired by science education in the light of Cultural Historical Activity Theory, and the recognition of the role of collectivity, co-operation and co-responsibility in science education inquiry. The general competences of the course include, among others, adapting to new situations, decision-making, teamwork, project planning and management, respect for difference and multiculturalism, and the production of free, creative and inductive thinking.

The main objective of the course during the 2020-2021 academic year was to train pre-service teachers so they would be able to develop an educational programme for a topic of science education in a museum space with sections didactically transformed so as to be a guide for science education in the early grades. The design of the educational programme was connected with the five frames of learning in the early grades (games, routines, everyday-life situations, explorations, organised learning activities), in which all early-grade pupils should participate equally, according to the early grades curriculum. Towards this direction, a series of activities, apart from lectures and workshops, was designed by the instructor, so that pre-service teachers would be able to conduct fieldwork, to expand the learning community, and to approach socio-cultural aspects and trends during their studies. Visiting museums and science centres and collaborating in participatory methods were some of the planned activities which took place virtually due to the pandemic. During the whole semester, the development of communicative skills, collaborative and creative work, problem solving, and critical thinking were among the priorities of the course.

\section{CHAT as a theoretical framework}

Cultural Historical Activity Theory (CHAT) is used as a theoretical framework in this paper for the design and the analysis of the course 'The Role of the Museum in Science and Technology Education'. CHAT supports the design of formative interventions that go beyond transmitting knowledge, and involve an opening to society, linking knowledge with everyday life, and the development of competences connected with socio-scientific issues (Engeström, 2019). The unit of analysis is the activity which includes the person or group who is acting towards an object, following certain rules, and the dynamic relationships developed within the activity system (Engeström, 1999; Barab et al., 2004; Lee, 2015). The object is a fundamental concept in CHAT (Blunden, 2013). In fact, it generates an activity system as it provides motivation towards the desired aim as well as the outcomes of the activity. Science as a learning object is not considered an isolated task of a curriculum, but is incorporated into general education, which aims at the development of the individual through the development of skills, as well as a positive attitude towards creativity and progress on 
a personal and a social level. As museums are strong cultural institutions, in which learners meet their social, cultural and historical environment (Plakitsi, 2008), they can offer learning opportunities beyond the walls of a school classroom in science education and education for sustainability. Scientific research faces global challenges, such as water and air pollution, climate change, life on earth, health, medicine, etc, all of which involve knowledge and action, as well as a commitment to society. Education in this context involves crossdisciplinary approaches, as well as the study of interactions between teachers, learners and the environment (UNESCO, 2009). Contradictions that emerge within and between the activity systems are tensions that lead to change and innovation (Engeström, 2015).

This course followed the basic parts of SCOPES (Systems of activity, Contradictions, Outcomes, Praxis, Expansive learning, Science education), a methodological tool for science education in early childhood and primary education based on CHAT (Kolokouri et al., 2019). Within this framework, the course was developed in an expansive cycle of learning (Engeström, 2015), which consists of a sequence of learning actions. Contradictions within the activity system were explored in order to reach the object. Science education in museum environments was considered a collective activity in which mediating tools and artefacts were used. Pre-service teachers were motivated to connect experience from society, culture and history with learning through participatory methods.

\section{Research questions}

It seems obvious that in the light of the new health conditions concerning the whole world, contemporary challenges of promoting a different kind of education have come up. Influences from new technology, media and computer tools are known to have a strong impact on students' learning, but what about the deprivation of communication with others, and the possible feelings of alienation from the real learning environment? The role of education at this point was to produce educational material which would inspire learners on one hand, and focus on developing skills of caring and belonging on the other, rather than simply follow scientific fact-oriented education. The new situation brought us to three major questions regarding the aim of creating innovative educational material and reaching an outcome within the distance learning course:

- What were the pre-service teachers' views of distance museum education?

- What were the conflicts/contradictions during the distance learning course?

- What were the connections of scientific topics with the 17 Sustainable Development Goals that preservice teachers made?

\subsection{Methodology}

Participants in 'The Role of the Museum in Science and Technology Education' course were 88 pre-service teachers during the last winter semester of their studies in the Department of Early Childhood Education at the University of Ioannina, Greece. During the whole semester, a series of topics concerning science education in museums were dealt with, such as:

- Contemporary trends and prospects of teaching science in museums.

- Links between museum education and science education in research, study curricula and teaching practice.

- Distance learning museum education. Virtual tours and museum kits.

- The relationship between scientific museums and schools in Greece. Possibilities and perspectives.

- Interaction between natural science and technology museums with the contribution of modern digital technologies.

- Familiarisation and critical reflection of educational programmes of museum education for science education.

- The teacher's role in educational programme planning..

- The connection between museum education and the 17 Sustainable Development Goals 
- The analysis and evaluation of educational programmes in the light of Cultural Historical Activity Theory (CHAT).

- The planning and creation of an educational programme for the topic of science education in the museum space.

The course was developed in the expansive cycle of Engeström (Figure 1), which puts an emphasis on the interpretation of the strategic learning actions and corresponding contradictions in expansive learning. According to Engeström and Sannino (2012), expansive learning puts the priority on communities as learners who create and transform culture and finally form theoretical concepts. Through collective activity that involves change, learners construct new knowledge and put it into practice in new situations. The series of learning actions used in this course are presented below as steps in an expansive cycle:

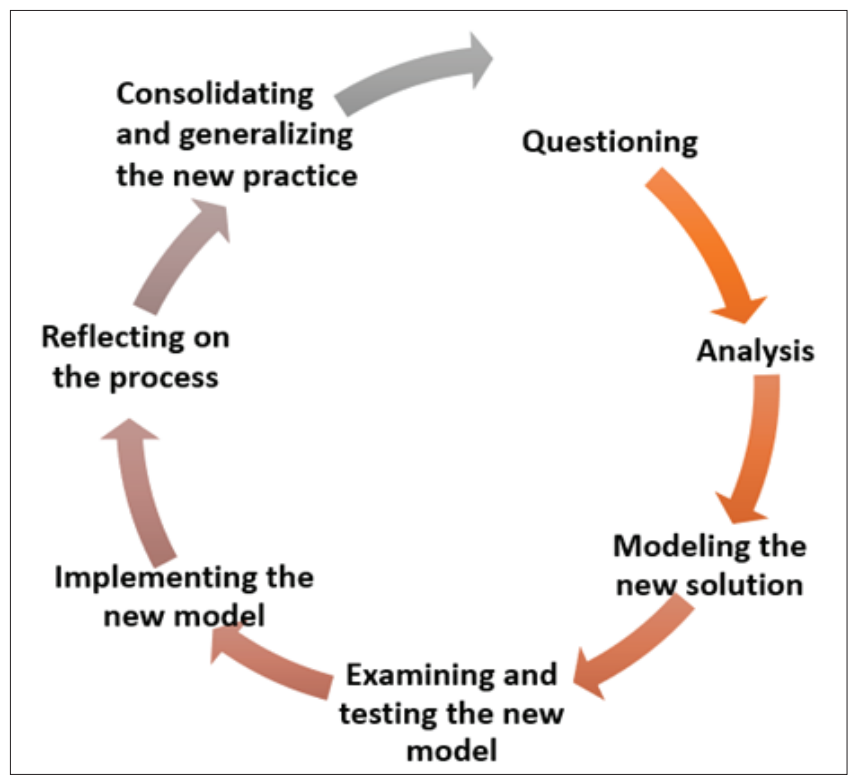

Figure 1. The sequence of epistemic actions in an expansive learning cycle

Source: Engeström, 1999.

Questioning: Redesign of the course 'The Role of the Museum in Science and Technology Education' so as to meet the needs for distance learning and to deal with the topics of the course at the same time.

Analysing the situation: This part included the analysis and comprehension of existing methods and practices of museum education, and links with science education and sustainable development. The analysis was conducted through educational curricula both at a local and an international level, so as to develop participatory activities and educational material.

Modelling: This part concerned the development of a series of online lessons for the course, which included lectures, virtual museum tours, application of participatory methods, and a series of assignments for pre-service teachers connected with the topics of the course. This consisted of a sequence of learning tasks which resulted in educational scenarios about science education in museums, and developed a virtual science museum with science education activities and connections with the 17 Sustainable Development Goals.

Examining-Implementing the model: In cooperation with the instructor of the course, pre-service teachers explored certain aspects of accepted practice and existing knowledge on science education in museums, as well as connections with the 17 Sustainable Development Goals. Furthermore, they discussed how the topics of the course would be adapted to early childhood education, and how pre-service teachers would do that if the course took place totally by distance learning. During this phase, pre-service teachers in groups 
designed educational scenarios and their own virtual museums, which were delivered as the final assignment of the course.

Reflecting and evaluating: In cooperation with the instructor of the course, pre-service teachers, discussed the prospects of the implementation of the educational scenarios and the virtual museums that had been designed, the connections with school curricula, the enrichment and extensions so that they can be put into practice, as well as the restrictions and limitations. At the same time, after gathering and reviewing preservice teachers' assignments, the instructor was able to assess whether the pre-service teachers were able to use the acquired knowledge and make didactic transformations in their educational scenarios for the early grades.

Consolidating the new practice: The instructor of the course finalised the online version of the course, and examined the case that this approach would also fit into different courses. The emphasis was put on the use of tools that would be appropriate for learning communities in different educational settings, as well as on the contradictions that occurred during the implementation of the course.

\subsection{Data gathering and analysis}

From the implementation of the course, quantitative as well as qualitative data was gathered. At the beginning of the course, the pre-service teachers answered an on-line questionnaire with closed-ended questions. The questionnaire was anonymous, and participants could have access by a link provided in the Ms Teams e-platform, as well as in the e-course platform of the university. The main objective was to explore pre-service teachers' views of visiting museums and museum education, so questions concerned mainly visiting museums, connections between museums and science education, the use of technology, the role of the teacher in museum educational programmes, and distance learning in museum education. In the present paper, only the results of the questions connected with distance learning in museum education will be presented.

Another questionnaire was used at the end of the semester and when the course was coming to an end, in order to gain an idea about the impact that the lockdown and the transition to distance learning had on preservice teachers, and to evaluate the distance learning tools and methods used in praxis. This matter will be addressed in the paper with the presentation of the results of selected questions from the questionnaire used.

An important aspect of the course, as well as in pre-service teachers' final assignment, was the connection between the science education curriculum in early grades and the 17 Sustainable Development Goals. Therefore, it was considered necessary to assess the extent to which pre-service teachers were able to identify these connections. In order to assess the above, QDA (Qualitative Data Analysis) Nvivo9 research software was used, to find the connections between scientific topics and the 17 Goals of Sustainable Development, by analysing the assignments of the pre-service teachers.

At the end of the course, a final assignment had to be prepared by pre-service teachers in groups. Each group had to develop a virtual museum using PowerPoint, and design an educational scenario for a scientific topic that can be taught through the virtual museum. In most cases, the educational scenarios were connected with the 17 Goals of Sustainable Development. The educational scenarios, in which pre-service teachers could use all the methods and strategies they had practised during the whole course, were designed for early-year pupils. As a next step, they had to analyse their work in a CHAT context, and, more specifically, to consider their assignment as a project, and describe the systems of activity that appear, as well as the contradictions within it.

\section{Results}

The results of the research will be presented with respect to the research questions of the paper, starting from the top. 


\subsection{What were pre-service teachers' views of distance museum education?}

Following the questionnaire that pre-service teachers answered at the beginning of the course, the results showed the sample's views of visiting museums, the frequency of visits to museums, and their perceptions of the contribution by the museum to the early years' education. Furthermore, their views of links between museums and science education and technology were investigated.

Regarding the question about distant learning courses in museum education, $56.8 \%$ of pre-service teachers confirmed that museum education can be implemented with distant learning courses, $36.4 \%$ said that museum education may be implemented with distant learning courses, while $4.5 \%$ provided a negative answer (Table 1).

Table 1. Can museum education be implemented with distant learning courses?

\begin{tabular}{|ll|l|l|l|l|}
\hline & & & & Cumulative \\
& & Frequency & Percent & Valid Percent & Percent \\
\hline Valid & Yes, it can & 50 & 56,8 & 56,8 & 56,8 \\
& No, it cannot & 4 & 4,5 & 4,5 & 61,4 \\
& Yes, it may & 32 & 36,4 & 36,4 & 97,7 \\
& I don't know & 2 & 2,3 & 2,3 & 100,0 \\
Total & 88 & 100,0 & 100,0 & \\
\hline
\end{tabular}

The tools for the implementation of distance learning in museum education that were suggested by preservice teachers were the use of virtual museum tours, the use of technology, the webpages and online material provided by the museums, and Skype meetings with museum curators. The use of technology during virtual tours is strongly connected with ICT tools and applications with which pre-service teachers have to be familiar, as is shown in the following graph (Figure 2).

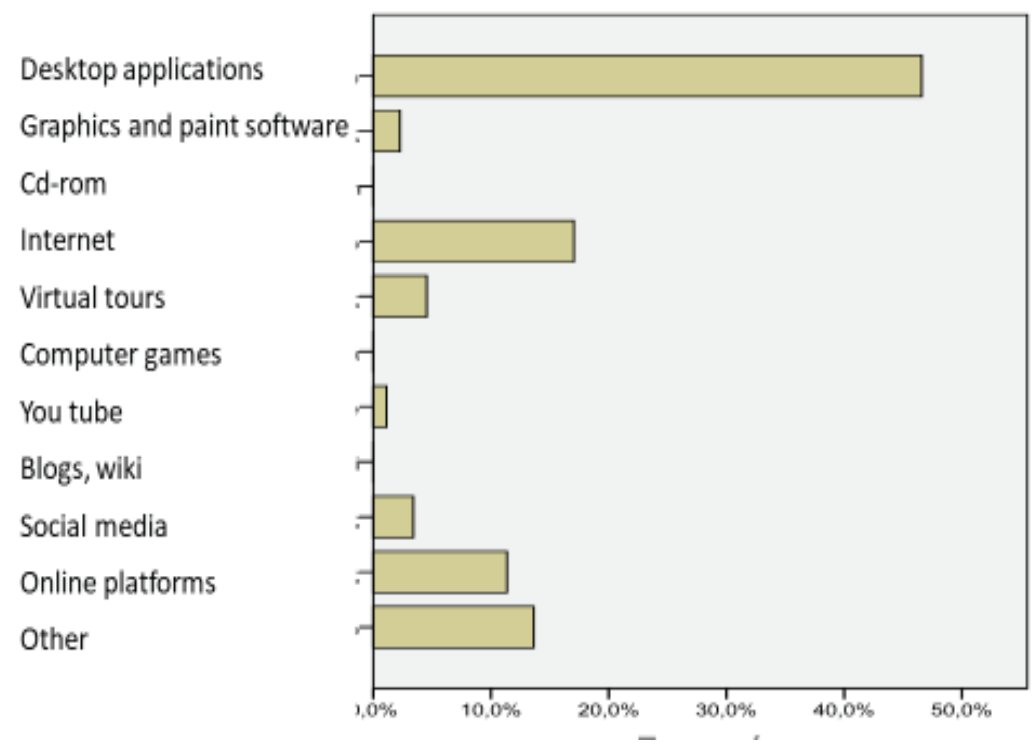

Figure 2. Which technology applications do you use? 
Pre-service teachers seem willing to use distance learning in museum education, as $84.09 \%$ answered yes to this question, while about $9 \%$ answered no, and about $6 \%$ answered I don't know (Figure 3).

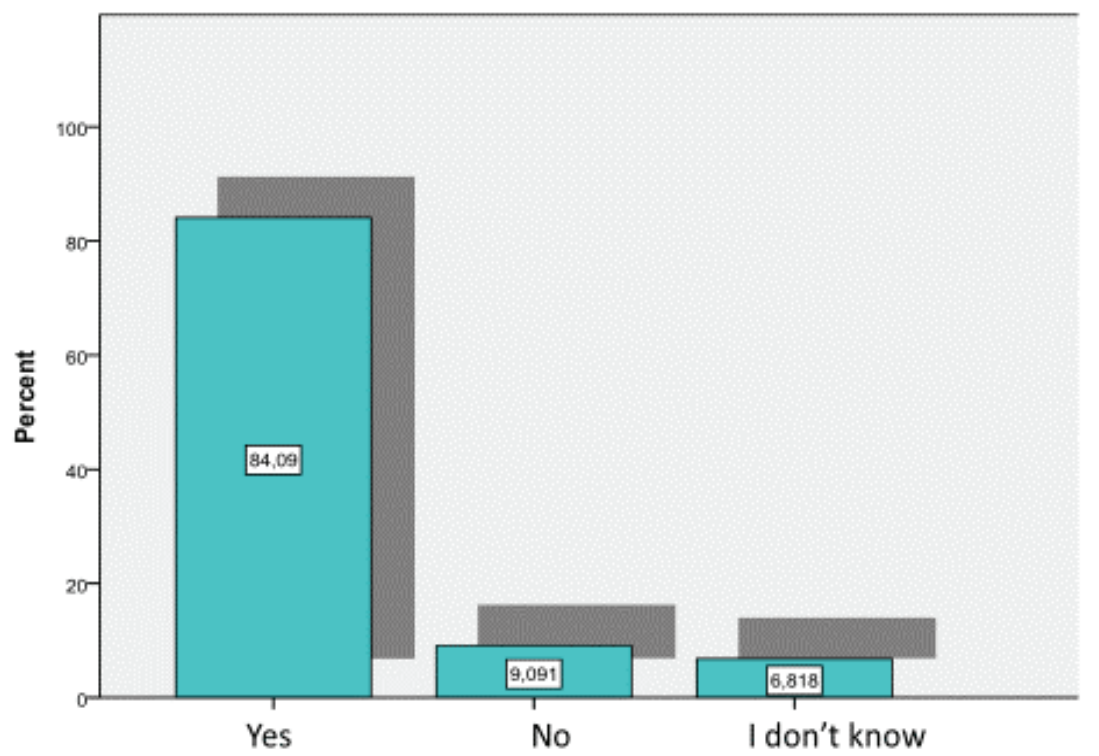

Figure 3. Are you willing to use distance learning in museum education in your future classroom?

Finally, $44.8 \%$ of pre-service teachers find it easy to use distance learning in museum education, $23.0 \%$ disagree, and $32.2 \%$ say they are not sure how it concerns their classroom in the near future (Table 2).

Table 2. Do you believe it is an easy task to use distance learning in museum education?

\begin{tabular}{|ll|l|l|l|l|}
\hline & & & & Cumulative \\
& & Frequency & Percent & Valid Percent & \begin{tabular}{l} 
Percent \\
\hline Valid
\end{tabular} YES \\
& NO & 39 & 44,3 & 44,8 & 44,8 \\
& I don't know & 28 & 22,7 & 23,0 & 67,8 \\
& Total & 87 & 31,8 & 32,2 & 100,0 \\
Missing & System & 1 & 98,9 & 100,0 & \\
Total & & 88 & 1,1 & & \\
\hline \hline
\end{tabular}

According to the above results, slightly over half the pre-service teachers are aware that museum education can be implemented remotely using ICT tools pointed out in the second question (Figure 2), while almost the other half believe that museum education may or cannot be implemented remotely (Table 1). What is important is that most of the pre-service teachers are willing to use distance learning museum education in their future classroom (Figure 3), although the replies about whether it is easy to implement are divided among the three answers (Table 2). It shows, though, that they probably have a positive stance, and are open to further training. 
4.2. What were the conflicts/contradictions during the distance learning course?

Following the questionnaire that pre-service teachers answered at the end of the course, the results showed the sample's views of the distance museum education that was implemented during the whole semester due to the pandemic situation of Coronavirus, the contribution of distance learning to the competences of pre-service teachers, and the conflicts/contradictions they faced during the distance learning course.

The development of competences during the distance learning course was tested through a series of questions, and as we can see in Table 3, respect for the environment is the most developed competence, in the sense that learning environments in museums were considered spaces for collaborative learning and developing innovative material that can be connected with respect and responsible citizenship. Teamwork, which was a basic way of working during the whole course, is a competence that was highly developed as well.

Table 3. The development of competences during the distance learning course

\begin{tabular}{lcc}
\hline & Mean & $\begin{array}{c}\text { Standard } \\
\text { Deviatior }\end{array}$ \\
\hline Adapting to new situations & 3,55 &, 848 \\
Decision-making & 3,52 &, 792 \\
Team work & 3,91 & 1,158 \\
Project planning and management & 3,57 &, 789 \\
Respect for difference and multiculturalism & 3,59 &, 923 \\
Respect for the environment & 4,14 &, 878 \\
Working in a transdisciplinary environment & 3,43 &, 818 \\
\hline Responsible citizenship & 3,59 &, 844 \\
\hline
\end{tabular}

The conflicts during the distance learning period (Figure 4) mainly concerned the labour of work, the disruption of personal life, personal knowledge of distance learning methods and possibilities, practical issues in the online connection and communication, and feelings of isolation.

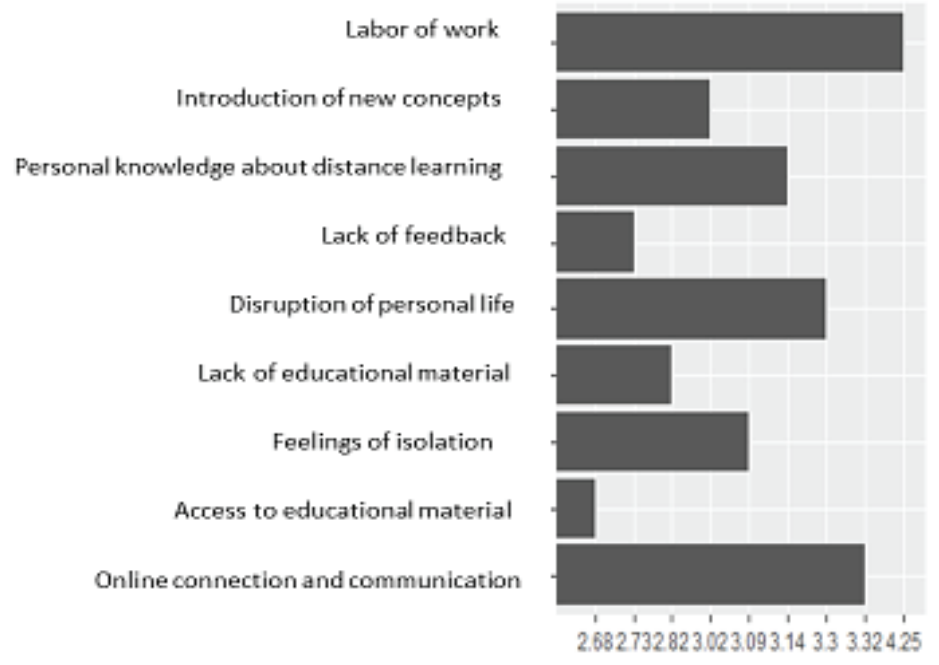

Figure 4. The conflicts / contradictions during the distance learning course 
Despite the conflicts mentioned above, the pre-service teachers found that the assignments they conducted during the course contributed to their learning, as $70 \%$ of the sample stated that assignments were helpful or very helpful during the course (Figure 5).

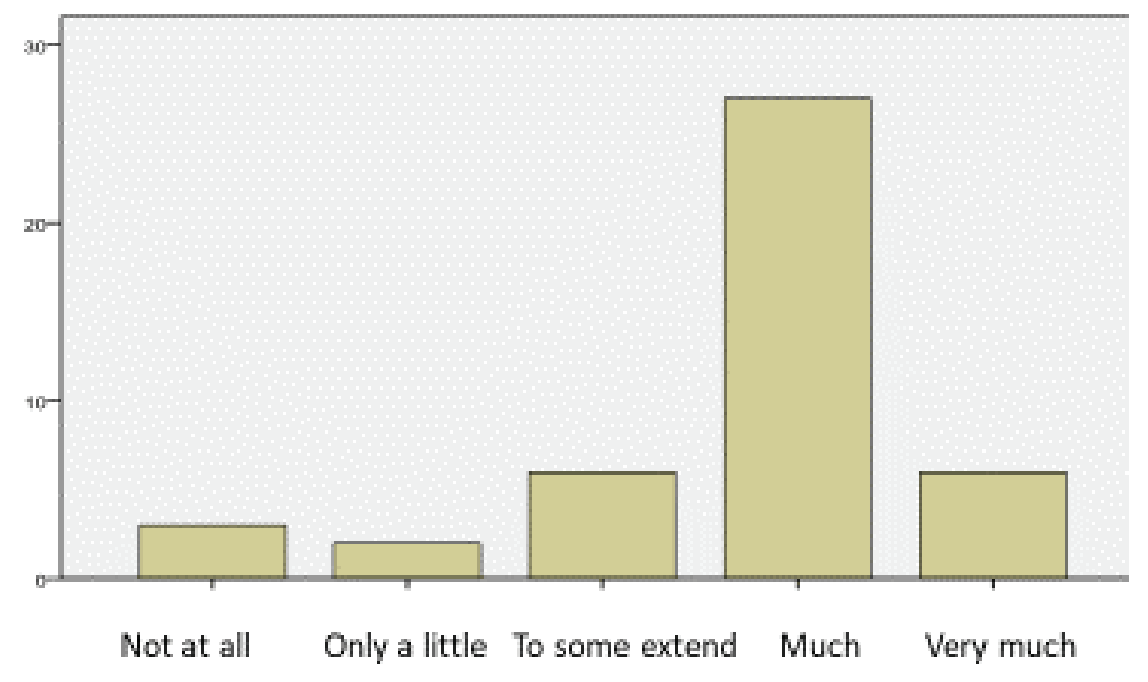

Figure 5. The contribution of the assignments during the distance learning course.

4.3. What were the connections between scientific topics and the 17 Sustainable Development Goals that pre-service teachers made?

Part of their final assignment was devoted to connections between the science education curriculum and its topics in early grades and the 17 Sustainable Development Goals. Identifying the connections was considered essential for pre-service teachers to take into account when designing their educational scenarios and virtual museums, since museums serve as strong agents of social change (Plakitsi, 2013).

Pre-service teachers were able to identify connections for all 17 Sustainable Development Goals, as is shown above (Figure 6). Some goals are equally connected with the four topics of science education in early grades, such as the fourth and the 17th goal, quality in education and partnerships for the goals respectively. Some goals are related mostly to the first topic 'living organisms', such as the first (no poverty), the second (zero hunger), the third (good health and well-being), the tenth (reduced inequality), the 14th (life below water), the 15th (life on land), and the 16th (peace, justice and strong institutions). The topic 'living organisms' obtained the most references (99). The topic 'objects and materials' took third place according to the number of references encoded in the node (54). It was mostly connected with goals number nine (industry, innovation and infrastructure) and 11 (sustainable cities and communities). Furthermore, the topic "concepts and phenomena of the natural world' in second place (64 references) was mostly connected with goals six (clean water and sanitation), seven (affordable and clean energy), eight (decent work and economic growth), 13 (climate action) and 14 (life below water). Finally, the topic 'planet Earth and space' is in fourth place based on the number of references (18), and it was mostly connected with the seventh and 11th goals, apart from the fourth and 17 th goals. 


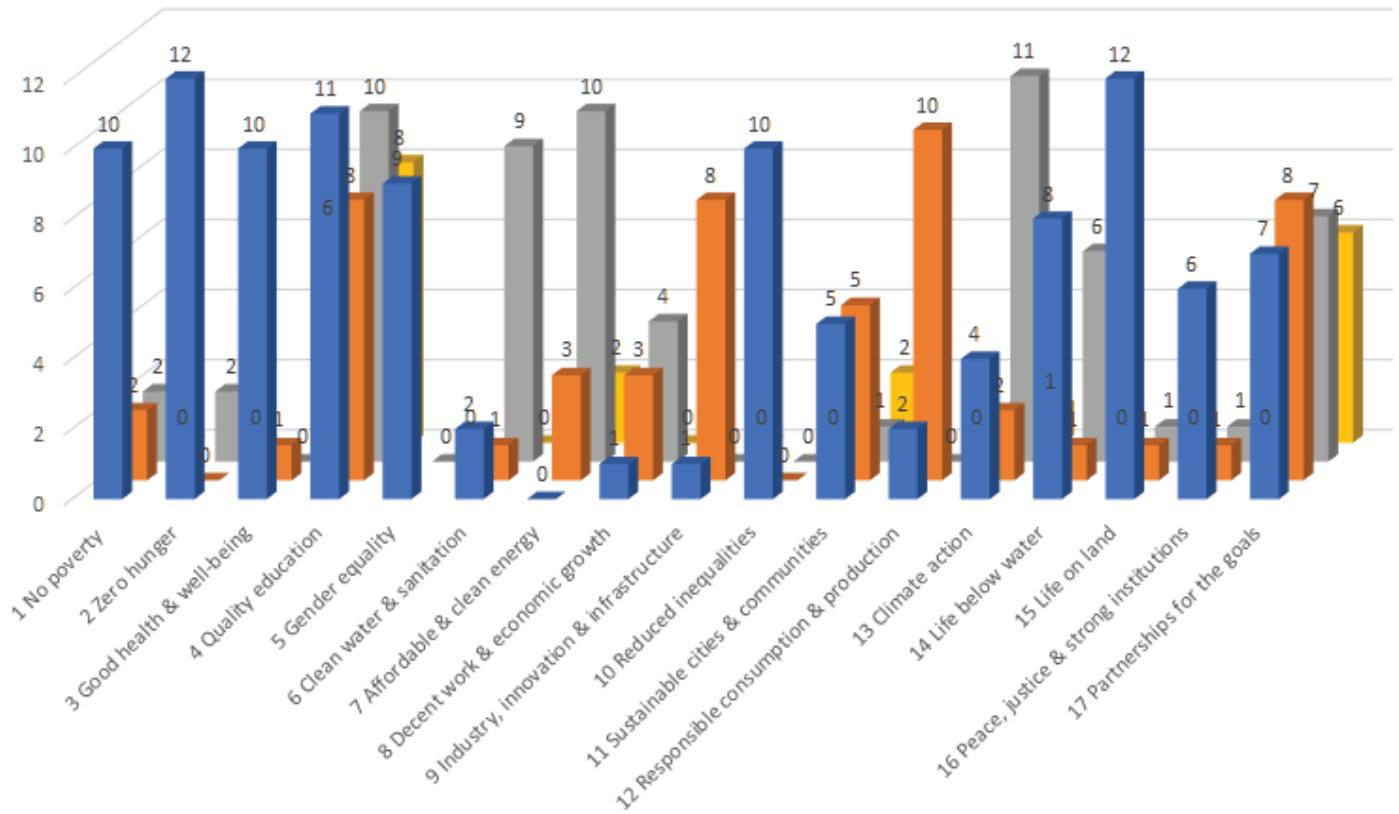

- Living organisms $\quad$ Objects \& materials $\quad$ Concepts \& phenomena of the natur al world $\quad$ Planet Ea th \& space

Figure 6. The 17 SDGs related to the topics of science education in early grades

\section{Discussion and conclusions}

This paper focused on presenting the implementation and prospects of a distance learning course during the pandemic situation of Covid 19. The main idea was to take advantage of distance learning facilities, and create appropriate settings for pre-service teachers in the area of science education in museums. The development of the course followed an expansive learning cycle (Engeström, 1987; Engeström, Sannino, 2012; Plakitsi et al., 2018). In the course of its development, the subjects of the activity system were pre-service teachers and the teaching instructor on the course. Their actions were influenced not only by their sociocultural background but also by the new situation that came up due to the Coronavirus pandemic. The tools they used to achieve the objective were adapted to the distance learning situation, as all university courses were held through the Microsoft Teams e-platform. The object of the pre-service teachers was to design educational material for early years education. The outcome included the development of teaching competencies concerning science education in museums. The community was mainly restricted to pre-service teachers and the teaching instructor of the university course, communicating through the e-platform, although in limited circumstances collaborators with the university took part in on-line meetings. The rules included the instructions of the university community about distance learning, as well as rules set by pre-service teachers to facilitate online collaboration. Finally, the division of labour referred to group work and the sharing of responsibilities.

Within this framework, pre-service teachers participated in a series of learning actions that led to the development of educational scenarios and virtual museums that they will be able to use in their future classrooms, and act not as knowledge transmitters but as designers of formative interventions that can make a difference in their professional lives.

The analysis of the activity system, as well as the monitoring and supporting of the process, was made possible by all the inputs gathered throughout the implementation of the course. Students' views of museum 
education and the prospects of distance learning museum education were taken into account by the instructor, who adapted the content to meet students' needs and sociocultural backgrounds. Furthermore, it was important for students to evaluate the course's outcomes by giving their own meanings and evaluating their learning process themselves in a dynamic learning community where students have a voice and influence the process. The distance learning process in the development of students' competences seems to be an efficient mediator, since students recognised that they managed to develop a respect for the environment, teamwork, respect for difference and multiculturalism, responsible citizenship, project planning and management, adapting to new situations, decision-making, and working in a transdisciplinary environment. Of course, conflicts were also present in the process, as students consider that the labour of work increased, and that there was a disruption in their personal life. Their lack of personal knowledge about distance learning methods and possibilities was a barrier to their learning, as were the practical issues in the online connection and communication, and the strong feelings of isolation and lack of interpersonal communication with their peers and the instructor. On the other hand, the conflicts that occurred were not inhibiting, because students themselves find the assignments given by the instructor helpful or very helpful in the learning process. The results of the analysis of students' assignments with the connections they made between the science education curriculum in early grades and the 17 Sustainable Development Goals confirm all of the above. Students not only managed to identify the connections, but they were also able to exploit them in the design of their virtual museums.

Using CHAT as a theoretical framework, and SCOPES as a method of design and analysis, encouraged pre-service teachers to move across a zone of proximal development of their activity system, rather than reach pre-defined goals. CHAT offers a cross-scientific field of action, in which authority and expertise are put under question, and, moreover, shows ways in which authority transforms from personal to collective activity in which motivation is high. Motivation includes challenge in order to satisfy the need for achievement, choice and independence in students' learning, and the expansion of the learning community (Plakitsi et al., 2018). This course supported the fact that science museums constitute strong agents for social change (Plakitsi, 2013), in which science is used as a tool for scientifically literate societies and participatory citizenship.

There are certainly limitations and restrictions in this study, since it concerns a specific university course, and the impact cannot be demonstrated at a general level. Further research, as well as the implementation of the educational scenarios that pre-service teachers developed, would reveal useful information about science education in museums, connections with sustainable development, and the role of distance learning.

Nevertheless, this course shows the example of the efforts university education in Greece made to overcome at first the emotional crisis, and instantly tried to face the pandemic situation as a living experience, a perezhivanie, in which alternative methods of learning and transformative interventions can be implemented.

\section{References}

Barab, S. A., Evans, M. A., Baek, E. (2004). Activity theory as a lens for characterizing the participatory the unit. In D. H. Jonassen (ed.). Handbook of Research for Educational Communications and Technology, p. 199-214. Mahwah, NJ: Lawrence Erlbaum Associates.

Blunden, A. (2013). Cultural-Historical Activity Theory Glossary of Terms. Available on line: https://www.ethicalpolitics.org/ablunden/pdfs/Glossary_of_Cultural_Historical_Activity.pdf.

Dafermos, M. (2014). Vygotsky's analysis of the crisis in psychology: Diagnosis, treatment, and relevance. Theory \& Psychology, Vol. 24(2), p. 147-165.

Engeström, Y. (1987). Learning by expanding: An activity-theoretical approach to developmental research. Helsinki: Orienta-Konsultit.

Engeström, Y. (1999). Activity theory and individual and social transformation. In Y. Engeström, R. Miettinen, R. L. Punamäki (eds.). Perspectives on Activity Theory, p. 19-38. Cambridge University Press.

Engeström, Y. (2015). Learning by expanding: An activity-theoretical BOOK approach to developmental research. Second edition. Cambridge: Cambridge University Press.

Engeström, Y., Sannino, A. (2012). Whatever happened to process theories of learning? Learning, Culture and Social Interaction, Vol. 1(1), p. 45-56.

Engeström, Y. (2019). Expansive Learning and Concept Formation: Cycles, Germ Cells and Formative Interventions. Iscar Regional Conference, 19-24 March 2019, Ioannina, Greece. 
Georgopoulou, P., Koliopoulos, D. (2017). Archaeological museums as environments of informaland non-formal science and technological education: The case of Educative Islets. In V. Ferrara (ed.) Proceedings of the EdMuse Conference 'Education and Museum: Cultural Heritage and Learning', p. 100-103.

Kolokouri, E., Kornelaki, A. C. (2019). Introducing a new socio-cultural tool for Science Education in First Grades. SCOPES, Conference proceedings ISCAR 2019: Crisis in contexts, Ioannina, Greece, p. 87-101.

Kornelaki, A. C., Plakitsi, K. (2018). Thunderbolt hunt. Educational Program for Students from 5 to 9 Years Old in the Archaeological Museum of Ioannina. World Journal of Education, Vol. 8(4), p. 87-101.

Lee, Y. J. (2015). Activity Theory and Science Learning. In: R. Gunstone (eds.). Encyclopedia of Science Education. Springer, Dordrecht.

Museum Associations. (2013). Museums Change Lives. Retrieved January 15, 2021. Available on line: https://maproduction.ams3.digitaloceanspaces.com/app/uploads/2020/06/18145451/28032017-museums-change-lives-11.pdf

Plakitsi, K., Stamoulis, E., Theodoraki, X., Kolokouri, E., Nanni, E., Kornelaki, A. (2018). Cultural-Historical Activity Theory and Science Education: A new Dimension in STEAM Education (in Greek). Athens: Gutenberg.

Plakitsi, K. (2013). Activity Theory in Formal and Informal Science Education. The Netherlands: Sense Publishers.

Plakitsi, K. (2008). Didactics of Natural Sciences in Pre-School and Early School Age: Modern Trends and Perspectives (in Greek). Athens: Patakis.

SCWS. (2017). Tokyo protocol. Retrieved February 15, 2021. Available on line: https://scws2017.org/tokyo_protocol/

UNESCO. (2020). Distance learning during COVID-19 worsens educational inequality. Retrieved March 15, 2021. Available on line: https://news.cgtn.com/news/2020-04-26/Distance-learning-during-COVID-19-worsens-educational-inequality--Q0ouQ9TlQY/index.html

UNESCO-IBE. (2009). Conclusions and Recommendations of the 48th Session of the International Conference on Education (ED/BIE/CONFINTED 48/5). Geneva: UNESCO-IBE.

United Nations. (2015). Sustainable Development Goals. Retrieved February 15, 2021, Available on line: http://www. undp.org/content/undp/en/home/sustainable-development-goals.html

Zittoun, T. (2019). Crises in the Course of Lives, Crises in Sociary: A sociocultural approach, Conference proceedings ISCAR 2019. Crisis in contexts, Ioannina, Greece, p. 25-46.

\title{
MOKSLINIS UGDYMAS MUZIEJUOSE PANDEMIJOS METU
}

\author{
Eleni Kolokouri, Athina C. Kornelaki, Katerina Plakitsi \\ Joaninos universitetas (Graikija)
}

\section{Santrauka}

Šiame straipsnyje pristatoma nuotolinio mokymo kursų ikimokyklinio ugdymo mokytojams plètra, pagrindinị dèmesį skiriant gamtos mokslų ugdymui muziejuose, taikant informacines technologijas COVID-19 pandemijos protrūkio laikotarpiu. Siekiama nustatyti, kiek kurso mokymosi rezultatai pasiekti universiteto studentams mokantis nuotoliniu būdu. Atliekant tyrimą ikimokyklinio ugdymo mokytojų klausta nuomonès dèl nuotolinio muziejinio ugdymo. Svarbu paminèti, kad norèta sužinoti ne tik tai, kaip sekasi mokyti, bet ir kaip siekti darnumo, kaip mokslo temos susijusios su 17-a darnaus vystymosi tikslų, kuriuos Jungtinių Tautų valstybės narès numatė siekti iki 2030 m. 2015 m. priimtoje tvaraus vystymosi darbotvarkejje. Kurso dalyviai - 88 ikimokyklinio ugdymo mokytojai, Joaninos universiteto (Graikija) Ankstyvojo ugdymo katedroje studijuojantys paskutinį žiemos studijų semestrą.

Sukurta mokymo metodika, paremta istorinès-kultūrinès veiklos teorija, apėmė platų mokymosi ciklą, kuri sudarė atitinkamų mokymosi veiksmų seka. Kurso pradžioje ikimokyklinio ugdymo mokytojai atsakẻ $\mathfrak{i}$ internetu pateiktos anketos klausimus (uždaruosius). Kitas klausimynas naudotas semestro pabaigoje ir 
kursams einant ị pabaigą, siekiant ịvertinti praktiškai taikomus nuotolinio mokymo būdus. Kurso pabaigoje ikimokyklinio ugdymo mokytojai grupèse turèjo parengti galutinę užduotį: edukacinį scenarijų konkrečia mokslo tema ir sukurti virtualią pamoką virtualiame muziejuje.

Daugelis ikimokyklinio ugdymo mokytojų patvirtino, kad muziejinị ugdymą galima ịgyvendinti vykdant nuotolinio mokymo kursus, rengiant virtualias ekskursijas, taikant informacines technologijas. Nuotolinio mokymosi metu kilę konfliktai dažniausia buvo susiję su negebejjimu prisitaikyti ir vesti pamokas nuotoliniu būdu, asmeninio gyvenimo trikdymu, asmeniniu nuotolinio mokymosi metodų ir galimybių pažinimu, praktiniais internetinio ryšio ir bendravimo klausimais bei izoliacijos jausmu. Nepaisant pasitaikiusių konfliktų, muziejai traktuoti kaip erdvès, kuriose galima mokytis bendradarbiaujant ir dirbant komandoje kuriant naują medžiagą. Galiausiai ikimokyklinio ugdymo mokytojai galèjo per pamokas susieti ekspozicijas muziejuose ir darnaus vystymosi tikslus, $\mathfrak{i}$ kuriuos atsižvelgta kuriant ugdymo scenarijus ir virtualius muziejus. Apskritai, kurso dalyvių patirtis po kursų patvirtino, kad mokslo muziejai labai naudingi edukacijos procese, čia gali būti taikomi alternatyvūs mokymosi metodai, mokoma darnaus vystymosi tikslų igyvendinimo būdų. PAGRINDINIAI ŽODŽIAI: muziejus, švietimas, mokslas, kultūrinè istorinè veikla.

JEL KLASIFIKACIJA: I0; I00; I000.

Received: 2021-03-06

Revised: 2021-04-28

Accepted: 2021-05-04 